\title{
The Significance of Applying Wordless Picture Book in Teaching Chinese Children A Wordless Picture Book Reading Teaching Practice
}

Lei Tang ${ }^{1, a}$

\author{
${ }^{1}$ New York University \\ ${ }^{a}$ Email: leitang1023@163.com
}

\begin{abstract}
The article talks about wordless picture books as an important tool for teaching Chinese children in 4-5 years old. Since conventional picture book reading activities might limit children's language production and active participation to a certain extends. Applying some wordless picture book reading as the large group activity may allow more children to participate in the activity actively. It can provide further opportunities to develop their language and interaction skills in the narrative process. Children can use the pictures in the wordless book to build their understanding and social imagination and actively participate in reading activities. Because of the robust theories done before, this article implements and analyzes an interactive reading activity based on wordless picture books.
\end{abstract}

Keywords: Wordless Picture Books, Picture Books, Language Production

\section{INTRODUCTION}

A picture book is a book that combines pictures and words, and it reflects children's life. Those pictures in the book may play a more critical role than words in the book. Applying picture books in teaching can greatly promote children's reading and learning interests; picture books represented culture and knowledge through pictures and the storyline. It helped children exhibit the creative form and philosophy, which promoted their mental experience and growth [1].

There is a specific type of picture book called a wordless or almost wordless picture book. Wordless picture books are books that almost have no words, and visual pictures primarily play the narrative role [2]. Many pieces of research show that wordless picture books greatly improved children's active participation during reading. This is because there are no words in the book, children become the one who produces the narrative information [3].

In China, picture books are becoming an essential resource for teachers in Chinese teaching. Through picture book reading activities, teachers can transfer the knowledge in the book in a relaxed and pleasant atmosphere. Help children understand the content of the book. Furthermore, picture books can convey clear life values to children, fostering better learning and living habits. They also help children learn how to express themselves and control their emotions [4]. However, the application of picture books in teaching still has certain limitations. For example, reading activities can easily be turned into question-and-answer teaching. If children have too many questions, they will lose interest in reading. Each picture book not only tells the story but also contains special meanings and themes. Children must think and experience deeply from the story [4]. Moreover, during the activity, the questions raised by the teacher may be too challenging for some students, so the students always show active participation in class time, which significantly reduces their language output efficiency.

Compared to the conventional picture book, the wordless picture book is a particular category of picture books, and they usually use vivid, life-like, and colorful images to tell the story; each page has to be more expressive and narratively than the conventional picture book. The author needs to use obvious scenes to make a connection between pages. The use of wordless picture books as a resource in teaching provides more space for developing children's cognition and language skills and fosters their reading interest and self-confidence.

This article analyses how the wordless picture book reading activity fosters children's language production 
and narrative capability and how it promotes children's active participation during the lesson.

\section{LITERATURE REVIEW}

\subsection{Wordless Picture Books reading foster children's language production (narrative capability)}

\subsubsection{Research had been done worldwide}

Narrative capability is one of the essential language goals that teachers and parents were pursuing at an early age. Many teachers are using picture books as the resource for children to practice their storytelling. Compared to conventional picture books; wordless picture books boost further value on language production. In the study of Chaparro-Moreno, Reali and Maldonado-Carreno, they asked 52 children to participate in two different reading groups, one day for the wordless picture book reading activity and the other day for the regular text picture book reading activity. They conducted a specific analysis of children's language production, including the total number of words, vocabulary diversity, the total number of utterances and average utterance time when children were reading. The results show that the overall language output of both teachers and children in wordless reading is much higher than that of picture books with words [3].

Wordless picture book reading can be one of the effective ways to promote children's storytelling. Informed by Rizqiyani and Azizah's research, they studied how wordless picture books develop children's storytelling capability with children aged 5-6 years old. They asked 30 children to participate in the research to read the wordless picture book, and they made the observation sheet for data analysis. The results showed that wordless picture books positively affect children's storytelling from 5-6 years old. They were more flexible on imagination and word production, and this activity even boosted children's self-confidence [5].

In Serafini's view, reading non-word books is an open and rich visual experience for children. They need to spend time carefully interpreting images and illustrations while reading. For example, facial expressions, gestures, actions, and events need to be derived from the sequence of each picture. Teachers can guide children from implicit to an explicit understanding of visual images and narrative sequences, and then they will know how the guiding process can help children's narrative [6].

\subsubsection{Research had been done in China}

Some Chinese researchers have done relevant research about how wordless picture books promote children's narrative and storytelling in China. Li used the experimental intervention to explore the influence of shared reading with wordless picture books, and he randomly selected two classes as experimental group and control group with the same age groups (4-5 years old) in one of public pre-school [7]. He implemented the shared book reading intervention with wordless picture books for six weeks. The results indicated that using wordless picture books for shared reading can greatly improve children's narrative capability [7].

Yang and Zheng researched how interactive reading affects their narrative and storytelling capability with children aged 4-5 years old [8]. They randomly selected two classes with the same age groups (4-5 years old) in one public pre-school. One class became the experimental group to do the interactive reading A (27 children), another class became the control group B to do the interactive reading $\mathrm{B}$ ( 28 children). In reading group A, teachers would read the story two times, and the firsttime teacher would lead an interactive wordless picture book reading by asking children thoughtful questions, the second time teacher telling the whole story without any break. In reading group B, the teacher only read the same story once with thoughtful questions. Teachers lead both groups A and B for reading intervention for six weeks. After six weeks of intervention, the results showed that both group A and group B improved their narrative capability. Group A showed a higher ability to clarify the story plot and sequence details than group B. Yang and Zheng concluded that allowing children to experience the story as a whole after interactive reading may lead children to focus more on the story sequencing and constructions [8]. 


\section{DATA COLLECTION}

Table 1. Raising hands frequency and utterances in wordless (almost wordless) picture book reading activity and two random conventional picture book reading activities

In this table, the author have collected the data of raising hands frequency and utterances of each student on both wordless picture book reading activity and conventional picture book activities from recored teaching videos.

\begin{tabular}{|c|c|c|c|c|c|c|}
\hline \multirow[b]{2}{*}{ Number of Times } & \multicolumn{2}{|c|}{$\begin{array}{l}\text { Wordless (almost wordless) } \\
\text { picture book reading activity }\end{array}$} & \multicolumn{2}{|c|}{$\begin{array}{c}\text { Conventional picture book } \\
\text { reading activity } 1\end{array}$} & \multicolumn{2}{|c|}{$\begin{array}{c}\text { Conventional picture book } \\
\text { reading activity } 2\end{array}$} \\
\hline & $\begin{array}{l}\text { Raise Hands } \\
\text { Frequency }\end{array}$ & Utterance & $\begin{array}{l}\text { Raise Hands } \\
\text { Frequency }\end{array}$ & Utterance & $\begin{array}{l}\text { Raise Hands } \\
\text { Frequency }\end{array}$ & Utterance \\
\hline Student A & 4 & 1 & 2 & 1 & 2 & 1 \\
\hline Student B & 3 & 1 & 2 & 0 & 4 & 1 \\
\hline Student C & 3 & 0 & 3 & 1 & 2 & 1 \\
\hline Student D & 4 & 3 & 1 & 1 & 2 & 0 \\
\hline Student E & 7 & 2 & 4 & 2 & 3 & 0 \\
\hline Student F & 11 & 2 & 5 & 1 & 7 & 2 \\
\hline Student G & 8 & 2 & 5 & 2 & 5 & 2 \\
\hline Student $\mathrm{H}$ & 6 & 2 & 3 & 1 & 2 & 1 \\
\hline Student I & 6 & 3 & 5 & 1 & 3 & 1 \\
\hline Student J & 9 & 3 & 5 & 2 & 5 & 3 \\
\hline Student K & 14 & 6 & 1 & 1 & 2 & 1 \\
\hline Student L & 6 & 1 & 4 & 1 & 3 & 0 \\
\hline Student M & 5 & 1 & 5 & 2 & 0 & 0 \\
\hline Student N & 8 & 6 & 7 & 2 & 5 & 3 \\
\hline Student O & 1 & 1 & 0 & 0 & 1 & 1 \\
\hline Student P & 0 & 0 & 0 & 0 & 1 & 1 \\
\hline Student Q & 6 & 2 & 3 & 1 & 6 & 0 \\
\hline Student R & 5 & 3 & 2 & 1 & 5 & 2 \\
\hline Student S & 9 & 3 & 4 & 1 & 9 & 1 \\
\hline Student T & 5 & 3 & 6 & 2 & 5 & 1 \\
\hline
\end{tabular}

\section{TEACHING PRACTICE}

The author is currently teaching a group of 4-5-yearolds in a bilingual kindergarten in Shanghai. For Chinese teaching, traditional picture books will become the first choice for the primary teaching resources of Chinese courses. After leading a lot of regular picture book reading activities, the author found that in such a class, some questions were asked more solidly for the children, and the children have become accustomed to asking and answering questions. They will pay attention to the interestingness of the story instead of considering the discussion issues. When the topic becomes too dull, some children will lose attention directly. In addition, when the problem is too challenging for some "low incidence" children, they will never have the opportunity to think and talk during the activity.

In order to make reading activities more inclusive for everyone, on this basis, all previous related studies have been done. Therefore, the author intends to implement an interactive activity of wordless picture books in the same class. Furthermore, the whole process is recorded for analysis after the course is implemented.

Some questions need to be explored in the analysis: Does children's language production improve when using the wordless picture books during the lesson compared to our regular lessons? Does children's active participation increase? How does "shy children" 's participate during this lesson compared to other lessons? 


\section{IMPLEMENTING THE LESSON}

Since it is already the second semester of the school year, some children will soon reach five years old. Their Chinese verbal ability has improved a lot from the first semester. Most children can express themselves in complete sentences and ask questions based on what they see and hear. Some students need further practice to express themselves in complete sentences. Based on their strengths and needs, the author used an almost wordless book "Ant and Watermelon" to read with the children. This is an exciting book about how the ant community lives and how they help move a giant watermelon home. The author should make the children form a circle to talk to each other better and more comfortably during the activity. However, due to the Covid-19, they can only be required to sit row by row; and be spaced apart from each other. The reading activity will last 30 minutes.

The author would record the number of times they raised their hands and the number of times they spoke on a piece of paper. This record sheet will add the same content to the other two literacy classes (selected at random) this semester.

\section{RESULTS ANALYSIS}

From table 1.1, It can be found that the number of times children raised their hands in reading the almost wordless books is greatly increased compared to the number of times children raised their hands in reading conventional picture books. There might be two reasons for this change: First, this almost wordless book allows much more opportunities for children to talk about their imaginations and thoughts. Everyone is free to talk, and there is no right or wrong answer. Second, questions asked from picture books with words might limit children's thinking possibilities. Other children would stay as "non-active" when they found someone had already taken the only correct answer. The overall active participation is improved a lot compared to our general literacy lessons. Even "shy children" are encouraged to express themselves here. Student $O$ and Student D always kept silent when they asked thinking questions, but they were surprised to express themselves with complete sentences in almost wordless reading activities.

The total number of utterances (45) in reading the almost wordless book is also more extensive than the total number of times of their utterances (22 and 23) in reading conventional picture books. This data implies the teacher is offering more questions or chances to speak during the almost wordless picture book activity. This kind of children-centered reading process can help children develop sequential thinking, visual discrimination, inferential thinking skills [8].

\section{DISCUSSION}

There are still a few teachers and parents in China who use wordless picture books (or almost wordless picture books) for their children, especially children aged 4-5. Children of this age have more vocabulary than 3-4year-olds, and they can express themselves clearly and independently, and they are more willing to talk to people around them. In order to maximize children's language skills during this period, teachers and parents need to let children speak more. Picture books with words, but picture books without words also provide children with many valuable functions.

\section{CONCLUSION}

The article aims to evaluate how wordless picture books (almost wordless picture books) reading can promote children's language production and their active participation in reading activities. The data shows that using wordless picture books (almost wordless picture books) as teaching materials can significantly improve children's imagination and language skills, and at the same time, promote teachers' support. In addition, teachers can encourage different children to talk more because the questions can be open-ended, teachers can carry different expectations according to the degree of participation of different children [3].

\section{REFERENCES}

[1] J. Li, Value and implementation strategy of picture book teaching in kindergartens, in: Fujian Trade Association and Xiamen new curriculum reform research group. Compliation of papers of South China education information research experience exchange group (six), Fujian commerce and Trade Association, Xiamen new curriculum reform research group: Fujian Commerce and Trade Association, 2020:2.

[2] I. Nières-Chevrel, The narrative power of pictures: L'Orage (the thunderstorm) by anne brouillard, in:

T. Colomer, B. Kümmerling-Meibauer, \& C. SilvaDíaz (Eds.), New directions in picturebook research London: Routledge. 2010, pp. 129-128.

[3] L. J. Chaparro-Moreno, F. Reali, C. MaldonadoCarreöo, Wordless picture books boost preschoolers' language production during shared reading, in: Early Childhood Re- search Quarterly, 2017, 40:5262.

[4] J. Yang, X. Liang, H. Tang, L. Zhang, H. Chen, Research on the effectiveness of classroom teaching methods and means under the background of new curriculum reform (4 th $^{\text {th }}$ volume), in: Beijing Zhongjiao ZhiChuang Information Technology Research Institute, Beijing Zhongjiao ZhiChuang 
Information Technology Research Institute: Beijing Zhongjiao ZhiChuang Information Technology Research Institute, 2017:12.

[5] R. Rizqiyani, N. Azizah, The influence of wordless picture book to improve the ability of storytelling among preschool students, in: Advances in Social Science, Education and Humanities Research, 2018, 326: 427-430.

[6] F. Serafini. Exploring Wordless Picture Books, in: The Reading Teacher, 2014，68(1): 24-26.

[7] C. Li, Effects of wordless picture book tells the children to share their reading ability of intermediate, in: Tianjin: Tianjin Normal University, 2014.

[8] Y. Yang, F. Zheng, The impact of using wordless picture book interactive reading to improve narrative capability among children with age of 4-5, in: Journal of Educational Development (second half of the month), 2020(08):37-42.

[9] S. L. Knudsen-Lindauer, Wordless books: An approach to visual literacy, in: Children's Literature in Education, 1988, 19(3), 136-141. 